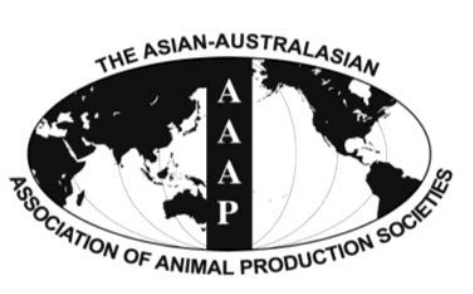

Open Access

Asian Australas. J. Anim. Sci.

Vol. 27, No. 5 : 733-742 May 2014

http://dx.doi.org/10.5713/ajas.2013.13540

www.ajas.info

pISSN 1011-2367 elSSN 1976-5517

\title{
Effect of Glucagon-like Peptide 2 on Tight Junction in Jejunal Epithelium of Weaned Pigs though MAPK Signaling Pathway
}

\author{
Changsong Yu ${ }^{1,2}$, Gang Jia ${ }^{1,2, *}$, Yi Jiang ${ }^{1,2}$, Qiuhong Deng ${ }^{1,2}$, Zhengli Chen ${ }^{3}$, Zhiwen $\mathrm{Xu}^{3}$, \\ Xiaolin Chen ${ }^{1,2}$, and Kangning Wang ${ }^{1,2}$ \\ ${ }^{1}$ Animal Nutrition Institute, Sichuan Agricultural University, Ya'an, Sichuan, 625014, China \\ ${ }^{2}$ Key Laboratory of Animal Disease-Resistance Nutrition and Feed Science, \\ Ministry of Agriculture, Ya'an, Sichuan, 625014, China
}

\begin{abstract}
The glucagon-like peptide 2 (GLP-2) that is expressed in intestine epithelial cells of mammals, is important for intestinal barrier function and regulation of tight junction (TJ) proteins. However, there is little known about the intracellular mechanisms of GLP-2 in the regulation of TJ proteins in piglets' intestinal epithelial cells. The purpose of this study is to test the hypothesis that GLP-2 regulates the expressions of TJ proteins in the mitogen-activated protein kinase (MAPK) signaling pathway in piglets' intestinal epithelial cells. The jejunal tissues were cultured in a Dulbecco's modified Eagle's medium/high glucose medium containing supplemental 0 to $100 \mathrm{nmol} / \mathrm{L}$ GLP-2. At $72 \mathrm{~h}$ after the treatment with the appropriate concentrations of GLP-2, the mRNA and protein expressions of zonula occludens-1 (ZO-1), occludin and claudin-1 were increased ( $\mathrm{p}<0.05)$. U0126, an MAPK kinase inhibitor, prevented the mRNA and protein expressions of ZO-1, occludin, claudin-1 increase induced by GLP-2 (p<0.05). In conclusion, these results indicated that GLP-2 could improve the expression of TJ proteins in weaned pigs' jejunal epithelium, and the underlying mechanism may due to the MAPK signaling pathway. (Key Words: Glucagon-like Peptide 2, Weaned Pig, Tight Junction, Jejunal Epithelium, Mitogen-activated Protein Kinase Signaling Pathway)
\end{abstract}

\section{INTRODUCTION}

Tight junction (TJ) is an important mode of cell-to-cell adhesions in the epithelial and endothelial cellular sheets, which act as a primary barrier that prevents the diffusion of solutes through the intercellular space, especially in the intestine (Tsukita et al., 2006). Weaned pigs are exposed to various stresses (e.g. the changes of feed, environment and ablactation) and infections caused by enterotoxigenic Escherichia coli (Osek, 1999). These factors reduce the expression of intestinal TJ proteins and increase the epithelial permeability of intestines (Bruewer et al., 2003).

\footnotetext{
* Corresponding Author: Gang Jia. Tel: +86-0835-2885005, Fax: +86-0835-2885005, E-mail: jiagang700510@163.com

${ }^{3}$ College of Animal Medicine, Sichuan Agriculture University, Ya'an, Sichuan, 625014, China.

Submitted Sept. 1, 2013; Revised Dec. 3, 2013; Accepted Jan. 5, 2014
}

The glucagon-like peptide 2 (GLP-2), an intestinotrophic growth hormone, in recent years has been proved to have the biological function of rapidly improving the intestinal epithelial barrier. It could significantly reduce intestinal fluxes of $\mathrm{Na}^{+}$, Cr-EDTA (Cameron et al., 2005), horseradish peroxidase (HRP) (Benjamin et al., 2000; Cameron et al., 2005), and bacterial penetration and colonic inflammatory cells (Cameron et al., 2005). Under stress conditions, GLP2 effectively enhances the barrier function and reduces the amount of luminal antigen that penetrates the lamina propria (Cameron et al., 2003). Cameron et al. (2005) thought these effects were due to changes in the TJ proteins induced by GLP-2. GLP-2 could recover and maintain the integrity of the intestinal mucosa epithelium barrier by increasing the expressions of zonula occludens-1 (ZO-1), claudin-1 and occludin in obstructive jaundice rats (Chen et al., 2008). GLP-2 could modulate the intestinal cells' proliferation and apoptosis via the ERK1/2 dependent

Copyright $@ 2014$ by Asian-Australasian Journal of Animal Sciences This is an open-access article distributed under the terms of the Creative Commons Attribution Non-Commercial License (http://creativecommons.org/licenses/by-nc/3.0/), which permits unrestricted non-commercial use, distribution, and reproduction in any medium, provided the original work is properly cited. 
mechanism (Burrin et al., 2001). However, there are no studies of GLP-2 regulating the expression of TJ proteins in the weaned pigs jejunal epithelium. Therefore, the present experiments were conducted to determine the effect of GLP-2 on intestinal tight junction in weaned pigs and to test the hypothesis that mitogen-activated protein kinase (MAPK) signaling pathway plays an important role in GLP2-mediated modulation of the TJ proteins.

\section{MATERIALS AND METHODS}

The protocol of the present experiment was approved by the Animal Care and Use Committee, Sichuan Agricultural University, Ya'an, China.

\section{Weaned pig jejunal tissue culture}

Three weaned DLY (Duroc $\times$ Landrance $\times$ Yorkshire) pigs (28 $\mathrm{d}$ of age) were starved for $12 \mathrm{~h}$ (the average body weight was $7.28 \pm 0.32 \mathrm{~kg}$ ). At that point, they were anaesthetized by the intravenous injection of chlorpromazine and subsequently killed by exsanguination. The abdomen was immediately opened and the jejunum was excised and dissected into small segments (5 to $7 \mathrm{~cm}$ ). The tissue segments were carefully rinsed in sterile PBS containing penicillin $(200 \mathrm{IU} / \mathrm{mL})$ and streptomycin $(200$ $\mu \mathrm{g} / \mathrm{mL}$ ) at $37^{\circ} \mathrm{C}$. Under sterile conditions, the jejunal tissue was dissected into $5 \mathrm{~mm}$ pieces in Dulbecco's modified Eagle's medium (DMEM) (Gibco) supplemented with 10\% fetal bovine serum (FBS) (Gibco), insulin (5 $\mu \mathrm{g} / \mathrm{mL})$, transferrin $(5 \mu \mathrm{g} / \mathrm{mL})$, penicillin $(100 \mathrm{IU} / \mathrm{mL})$ and streptomycin $(100 \mu \mathrm{g} / \mathrm{mL})$ for $24 \mathrm{~h}$. Then, two pieces of tissue were cultured in a single well which was pipetted with $1.5 \mathrm{~mL}$ of fresh culture medium with different concentrations of GLP-2 (Purity $\geq 95 \%$, Phoenix pharmaceuticals, USA). The concentrations of GLP-2 were 0,10 , and $100 \mathrm{nmol} / \mathrm{L}$ respectively. Also, 48 pieces of tissue were cultured for each individual level of medium. Tissues were maintained in 24 well culture plates (Corning) at $37^{\circ} \mathrm{C}$ in a humidified incubator in an atmosphere of $5 \% \mathrm{CO}_{2}$. The medium was replaced every $24 \mathrm{~h}$.

After being cultured for $72 \mathrm{~h}$, the tissue pieces were collected so that the effects of GLP-2 treatment on the TJ proteins and their mRNA expressions could be analyzed. Once the optimum dose of GLP-2 that could improve the protein expression of TJ proteins was established, another three DLY weaned piglets ( $28 \mathrm{~d}$ of age) were slaughtered (the average body weight was $7.65 \pm 0.58 \mathrm{~kg}$ ). The jejunal tissues were collected under sterile conditions and random pieces were transferred to a fresh medium in 24 well tissue culture plates. Further, two pieces of tissues were cultured in a single well in $1.5 \mathrm{~mL}$ of the culture medium. The culture medium contained: a control group, a $100 \mathrm{nmol} / \mathrm{L}$
GLP-2-treated group and a $100 \mathrm{nmol} / \mathrm{L}$ GLP-2 with 10 $\mu \mathrm{mol} / \mathrm{L}$ U0126 (Calbiochem-Novabiochem Corp, in San Diego, CA) -treated group. 48 pieces of tissues were cultured for each individual level of medium. Tissues were maintained in 24 well culture plates (Corning) at $37^{\circ} \mathrm{C}$ in a humidified incubator in an atmosphere of $5 \% \mathrm{CO}_{2}$. The medium was replaced every $24 \mathrm{~h}$. After being cultured for $72 \mathrm{~h}$, the jejunal tissues were collected and quickly frozen in liquid nitrogen and stored at $-80^{\circ} \mathrm{C}$ or to be used in subsequent trials.

\section{RNA isolation, reverse transcription and quantitative real time PCR}

TRIZOL reagent (TaKaRa) was added to samples of jejunal tissues. RNA extraction was performed using the chloroform/isopropyl alcohol method, followed by Qiagen RNeasy clean-up, according to the manufacturer's instructions. RNA was eluted from the column in $50 \mu \mathrm{L}$ of RNase-free water, and concentration and purity determined using a DU-800 spectrophotometer (Beckman, Brea, CA, USA). Reverse transcription PCR was performed using the PrimeScript RT reagent Kit with gDNA Eraser (Perfect Real Time) (Code No. RR047A; TaKaRa, China). Reaction conditions and PCR program followed the manufacturer's instructions. Different porcine gene specific primers (Invitrogen, Shanghai, China) were used (Table 1). Primer pairs were designed using Primer3 program based on NCBI porcine sequences.

Real time PCR (RT-PCR) was performed using a CFX96 real time PCR system (Bio-Rad, California, US) with the SYBR Premix Ex Taq TM II (Tli RNaseH Plus) (Code No. RR820A; TaKaRa, China). cDNA ( $1 \mu \mathrm{L})$ was added in a 25 $\mu \mathrm{L}$ reaction mixture which contained $12.5 \mu \mathrm{L}$ SYBR Premix Ex Taq II (Tli RNaseH Plus) $(2 \times), 10 \mu \mathrm{M}$ each primer, $2 \mu \mathrm{L}$ cDNA and $8.5 \mu \mathrm{L} \mathrm{dH} 2 \mathrm{O}$. The program setting was $30 \mathrm{~s}$ at $95^{\circ} \mathrm{C}$ and then 40 cycles of $95^{\circ} \mathrm{C}$ for $5 \mathrm{~s}, 53^{\circ} \mathrm{C}$ to $62^{\circ} \mathrm{C}$ (depending on the primers used) for $30 \mathrm{~s}$, and $72^{\circ} \mathrm{C}$ for $30 \mathrm{~s}$. On the completion of amplification, a melting curve was produced by holding the reaction mixture at $60^{\circ} \mathrm{C}$ to $95^{\circ} \mathrm{C}$ with a heating rate of $0.1^{\circ} \mathrm{C}$ per second and a continuous fluorescence measurement and finally a cooling step to $40^{\circ} \mathrm{C}$. The housekeeping gene encoding $\beta$-actin was used as an internal control. The analysis consisted of at least five independent experiments. Each experimental sample was assayed using three replicates for each primer. The Relative levels of the mRNA of the genes of interest were normalized to that of the $\beta$-actin mRNA and were determined using a modified $2^{-\Delta \Delta C t}$ method (Pfaffl et al., 2001).

\section{Western blotting analysis}

Western blotting was performed by the modified 
Table 1. Defined porcine gene primers for PCR and qRT-PCR

\begin{tabular}{|c|c|c|c|c|}
\hline Gene & Abbr. & Primer sequences ( $5^{\prime}$ to $\left.3^{\prime}\right)$ & $\begin{array}{l}\text { Annealing temperature } \\
\qquad\left({ }^{\circ} \mathrm{C}\right)\end{array}$ & $\begin{array}{c}\text { GenBank } \\
\text { accession no. }\end{array}$ \\
\hline \multirow[t]{2}{*}{$\overline{\mathrm{ZO}-1}$} & ZO-1-f & GACTTAAAGCTGCCTCAACA & 62.0 & XM003353439.2 \\
\hline & ZO-1-r & GGTTTGTTTCAGGCGAAAGT & & \\
\hline \multirow[t]{2}{*}{ Claudin-1 } & Claudin-1-f & TTCTGGGAGGTGCCCTACTT & 59.5 & NM001244539.1 \\
\hline & Claudin-1-r & TGGATAGGGCCTTGGTGTTG & & \\
\hline \multirow[t]{2}{*}{ Occludin } & Occludin-f & CCATGGCCTACTACTCGTCC & 59.5 & NM001163647.1 \\
\hline & Occludin-r & CGGCACCGGTGTTGATTTAT & & \\
\hline \multirow[t]{2}{*}{ ERK1 } & ERK1-f & TGCATTCTGGCTGAGATGCT & 55.9 & HM745137.1 \\
\hline & ERK1-r & TGAGCTGGTCCAGGTAGTGC & & \\
\hline \multirow[t]{2}{*}{ ERK2 } & ERK2-f & CCGTGACCTCAAACCTTCCA & 59.5 & HM590585.1 \\
\hline & ERK2-r & CCAACCCAAAGTCACAGATC & & \\
\hline \multirow[t]{4}{*}{ p90RSK } & p90RSK-f & ACCTGGTGTCAAAGATGCTTC & 59.5 & XM003134969.3 \\
\hline & p90RSK-r & CAGTGGACGATCCAAGGATGT & & \\
\hline & & TCGGAAGTGTGTATCCCGTAGG & & \\
\hline & & GCAAGGAACACGGCTAAGTTG & & \\
\hline
\end{tabular}

method of Kansagra et al. (2003). To summarize, $100 \mathrm{mg}$ of pulverised frozen tissue was homogenised in $1 \mathrm{~mL}$ of lysis buffer containing 50 mM-2-amino-2-hydroxymethylpropane-1, 3-diol (Tris)-HCl, $100 \mathrm{mM}$-phenylmethylsulfonyl fluoride, $0.5 \mathrm{mM}$-sodium dodecylsulfate and $1 \mathrm{mM}-$ dithiothreitol. After the protein concentration of supernatant fractions was quantized by a standard bicinchoninic acid (BCA) protein assay (Bio-Rad, USA), equal protein amounts (60 to $100 \mu \mathrm{g}$ ) were separated on $6 \%$ to $15 \%$ denatured SDS-PAGE gels and run at $100 \mathrm{~V}$ for $60 \mathrm{~min}$. Separated proteins were then transferred onto PVDF membranes (Bio-Rad, USA) at $90 \mathrm{~V}$ for 45 to $60 \mathrm{~min}$. The membranes were blocked with blocking buffer (concentrated saline and Hammersten casein solution) at room temperature for $1 \mathrm{~h}$ and probed with primary antibody overnight. The primary antibodies used were: polyclonal anti-claudin-1 (Santa Cruz Biotechnology Inc., California, USA) diluted 1:500, anti-occludin (Santa Cruz Biotechnology Inc., USA) diluted 1:450, anti-ZO-1 (Santa Cruz Biotechnology Inc., USA) diluted 1:400 and anti- $\beta$ actin (Cell Signaling Technology Inc., Massachusetts, USA) diluted 1:2,000. After being washed extensively to eliminate nonspecific binding, the membranes were incubated with a horseradish peroxidase-conjugated secondary antibody (anti-rabbit IgG) (Santa-Cruz Biotechnology Inc., US) at room temperature for $30 \mathrm{~min}$. The antibody-reactive bands were visualized using chemiluminescence.

The phosphorylated forms of specific signaling proteins in jejunal tissue were measured. Frozen jejunal tissue mucosa samples $(100 \mathrm{mg})$ were homogenized in $50 \mathrm{mM}$ HEPES buffer (pH 7.4) containing $1 \mathrm{mM}$ EDTA, $1 \mathrm{mM}$ dithiothreitol, $5 \mathrm{mg} / \mathrm{L}$ phenylmethylsulfonyl fluoride, 5 $\mathrm{mg} / \mathrm{L}$ aprotinin, $5 \mathrm{mg} / \mathrm{L}$ chymostatin, and $5 \mathrm{mg} / \mathrm{L}$ pepstatin added phosphatase inhibitor, sodium orthovanadate to a final concentration of $2 \mathrm{mM}$. The homogenate was then sonicated and centrifuged at $12,000 \mathrm{~g}$ for $15 \mathrm{~min}$ at $4^{\circ} \mathrm{C}$.
Equal amounts (60 to $100 \mu \mathrm{g}$ ) of supernatant protein extracts were separated on a $9 \%$ to $12 \%$ denatured SDSPAGE and transferred to PVDF membranes. The membranes were blocked with blocking buffer (concentrated saline and Hammersten casein solution) at room temperature for $1 \mathrm{~h}$ and probed with primary antibody overnight. The primary antibodies used were: polyclonal anti-p-ERK1/2 $\left(\mathrm{Thr}^{202} / \mathrm{Tyr}^{204}\right.$ ) (Santa Cruz Biotechnology Inc., USA) diluted 1:1,000, anti-p-p90RSK $\left(\operatorname{Ser}^{380}\right.$ ) (Santa Cruz Biotechnology Inc., USA) diluted 1:2000 and then the other manipulation and secondary antibody was administered as in the same way as noted above.

\section{Immunohistochemistry analysis}

Immunohistochemistry was done to assess the distribution of the TJ proteins ZO-1, claudin-1 and occludin. Every 3 jejunal tissue samples from each group were fixed in fresh neutral buffered $4 \%$ paraformaldehyde overnight. Samples were embedded in paraffin blocks, sectioned (5 $\mu \mathrm{m})$, and mounted on glass slides. All of sections were dewaxed in xylene and rehydrated and then boiled in 0.1 mol/L sodium citrate buffers ( $\mathrm{pH}$ 6.3) for antigen retrieval. mouse anti-ZO-1 (1:100; Cell Signaling Technology Inc., USA), mouse anti-claudin-1 (1:100; Cell Signaling Technology Inc., USA) and mouse anti-cccludin (1:150; Cell Signaling Technology Inc., USA) antibodies were applied to assess protein distribution in the tissues. The primary antibodies were used for about $12 \mathrm{~h}$ at $4{ }^{\circ} \mathrm{C}$. The biotinylated goat anti-mouse $\mathrm{IgG}$ was used as the secondary antibody. The immunoreactivity was visualized by the avidin-peroxidase method with no specific staining negative control experiments. The OD value of each sample was determined for the quantity access at a 400 magnification with a Carl Zeiss A200 microscope (Carl Zeiss, Germany), additional Image-Pro Plus 6.0 software. 


\section{Statistical analysis}

The statistical significance of differences was analyzed by the ANOVA procedure of SPSS Statistics 17.0 followed by Duncan's Multiple Range Test and T test. Results are presented as means \pm SEM. Differences were considered significant at $\mathrm{p}<0.05$.

\section{RESULTS}

mRNA expressions of tight junction and signaling molecules

The results showed that supplementing with GLP-2 significantly increased $(\mathrm{p}<0.05)$ the expression of ERK $1 / 2$ and p90RSK mRNA in the jejunal mucosa (Figure 1). Compared with the control, the expressions of ERK1, ERK2, p90RSK, ZO-1, claudin-1, occludin mRNA increased $85 \%, 195 \%, 47 \%, 29 \%, 120 \%$, and $54 \%$ respectively in the $10 \mathrm{nmol} / \mathrm{L}$ GLP-2-treated group and $301 \%, 747 \%, 883 \%, 59 \%, 251 \%$, and $142 \%$ respectively in the $100 \mathrm{nmol} / \mathrm{L}$ GLP-2-treated group while the abundance of total ERK1/2 protein was unchanged ( $>>0.05)$ (Figure 3).

As depicted in Figure 2, compared with the control, the addition of GLP-2 (100 nmol/L) could increase the expressions of ZO-1, claudin and occludin mRNA ( $\mathrm{p}<0.05)$ while these effects were blocked when U0126 (10 $\mu \mathrm{mol} / \mathrm{L})$ was simultaneously added into the medium with GLP-2. U0126 inhibited GLP-2-induced up regulation of ZO-1, claudin and occludin mRNA expressions $(\mathrm{p}<0.05)$. Compared with the $1 \times 10^{-7} \mathrm{~mol} / \mathrm{L}$ GLP-2-treated group, the mRNA expressions of ZO-1, claudin and occludin decreased $21.1 \%, 61.3 \%$, and $41.6 \%$ respectively in the 100 nmol/L GLP-2 with $10 \mu \mathrm{mol} / \mathrm{L}$ U0126-treated group $(\mathrm{p}<0.05)$.

\section{Protein expressions of tight junction and signaling molecules}

p90RSK is a downstream nuclear target of ERK1/2 and its expression increased after $72 \mathrm{~h}$ of GLP-2 treatment based on protein abundance. Both phospho-ERK1/2 and phospho-p90RSK abundance increased significantly $(\mathrm{p}<0.05)$. In comparison with the control group, the protein relative abundance of p-ERK1/2, p-p90RSK, ZO-1, claudin-1 and occludin increased $34.7 \%, 56 \%, 35.6 \%$, $30.4 \%$, and $26.2 \%$ respectively $(\mathrm{p}<0.05)$ in the $10 \mathrm{nmol} / \mathrm{L}$ GLP-2-treated group; the relative abundance increased $69.5 \%, 84 \%, 46.7 \%, 56.7 \%$, and $35.6 \%$ respectively $(\mathrm{p}<0.05)$ in the $100 \mathrm{nmol} / \mathrm{L}$ GLP-2-treated group (Figure 3).

As shown in Figure 4, in comparison with the control group, GLP-2 (100 nmol/L) increased the abundance of all protein $(\mathrm{p}<0.05)$. But when U0126 $(10 \mu \mathrm{mol} / \mathrm{L})$ was added
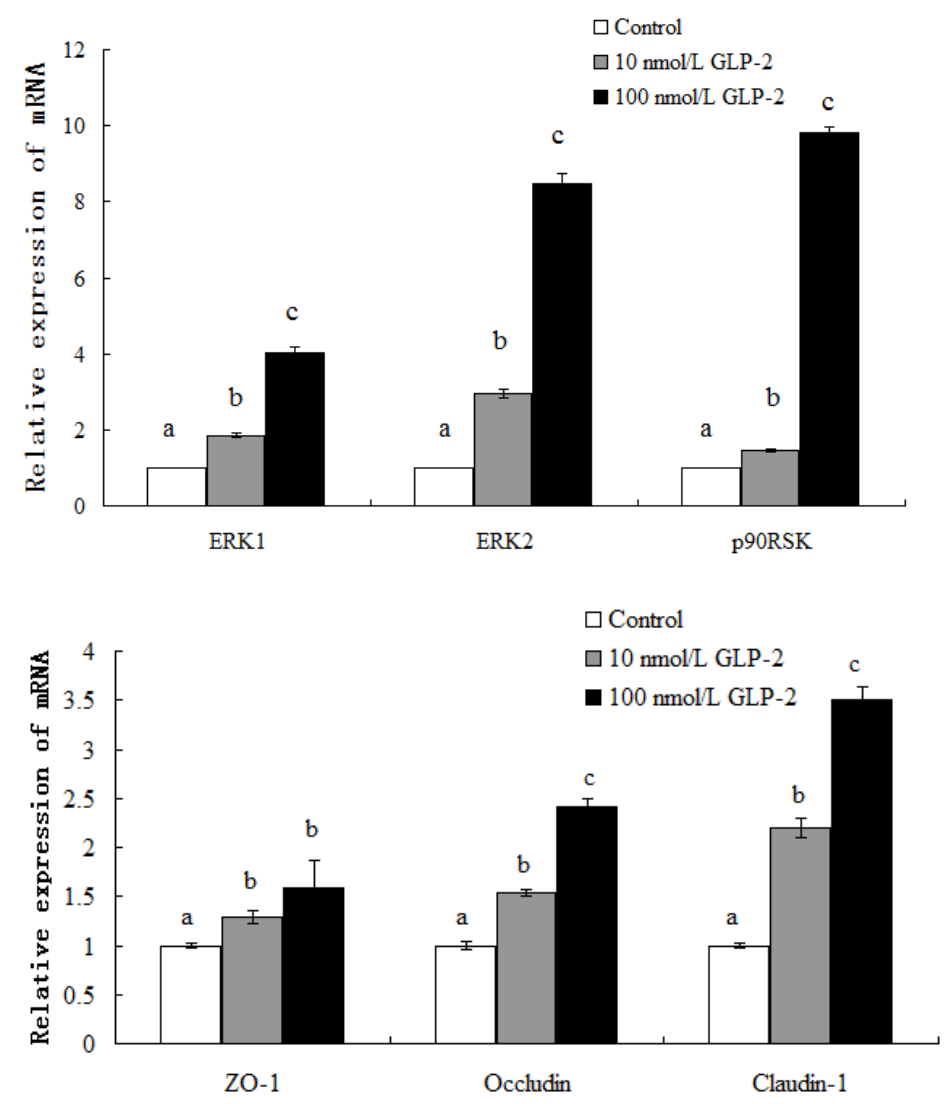

Figure 1. Effect of GLP-2 on tight junction proteins and signaling molecules mRNA expression. GLP-2, glucagon-like peptide 2. a,b,c Treatments with different letters are different at $\mathrm{p}<0.05$. 


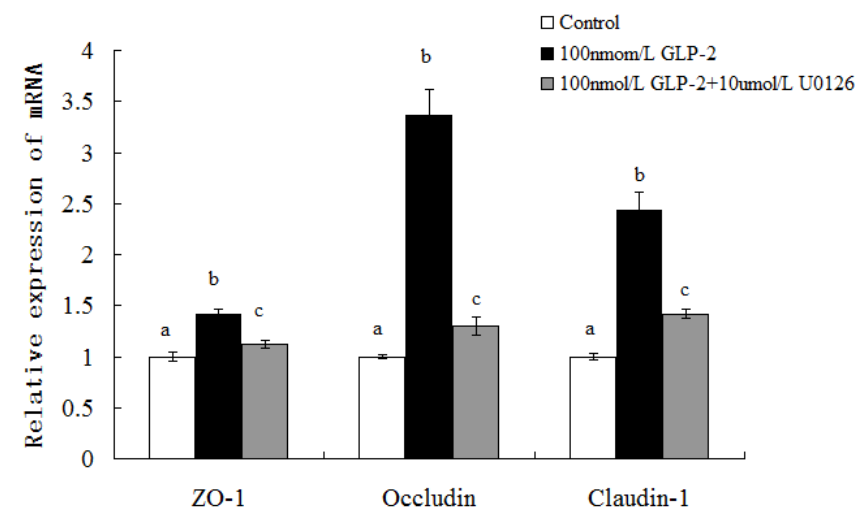

Figure 2. Effect of GLP-2 on tight junction proteins mRNA expression with MAPK signaling pathway blocked by U0126. GLP-2, glucagon-like peptide 2; MARK, mitogen-activated protein kinase; ZO-1, zonula occludens-1. ${ }^{\mathrm{a}, \mathrm{b}, \mathrm{c}}$ Treatments with different letters are different at $\mathrm{p}<0.05$.
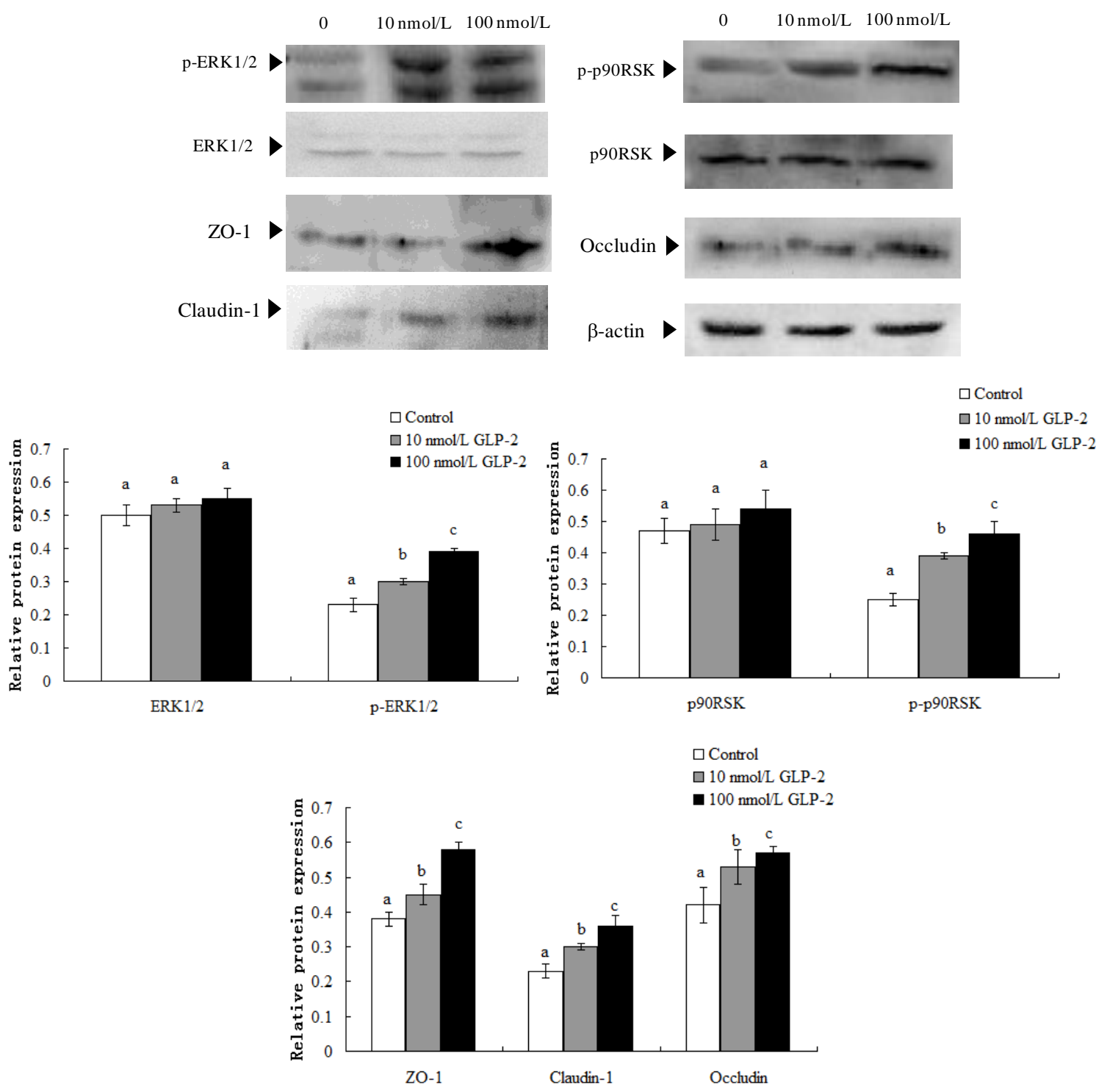

Figure 3. Effect of GLP-2 on tight junction proteins and signaling molecules expression. They are shown as bar graphs. GLP-2, glucagon-like peptide 2 ; ZO-1, zonula occludens-1. ${ }^{\mathrm{a}, \mathrm{b}, \mathrm{c}}$ Treatments with different letters are different at $\mathrm{p}<0.05$. 

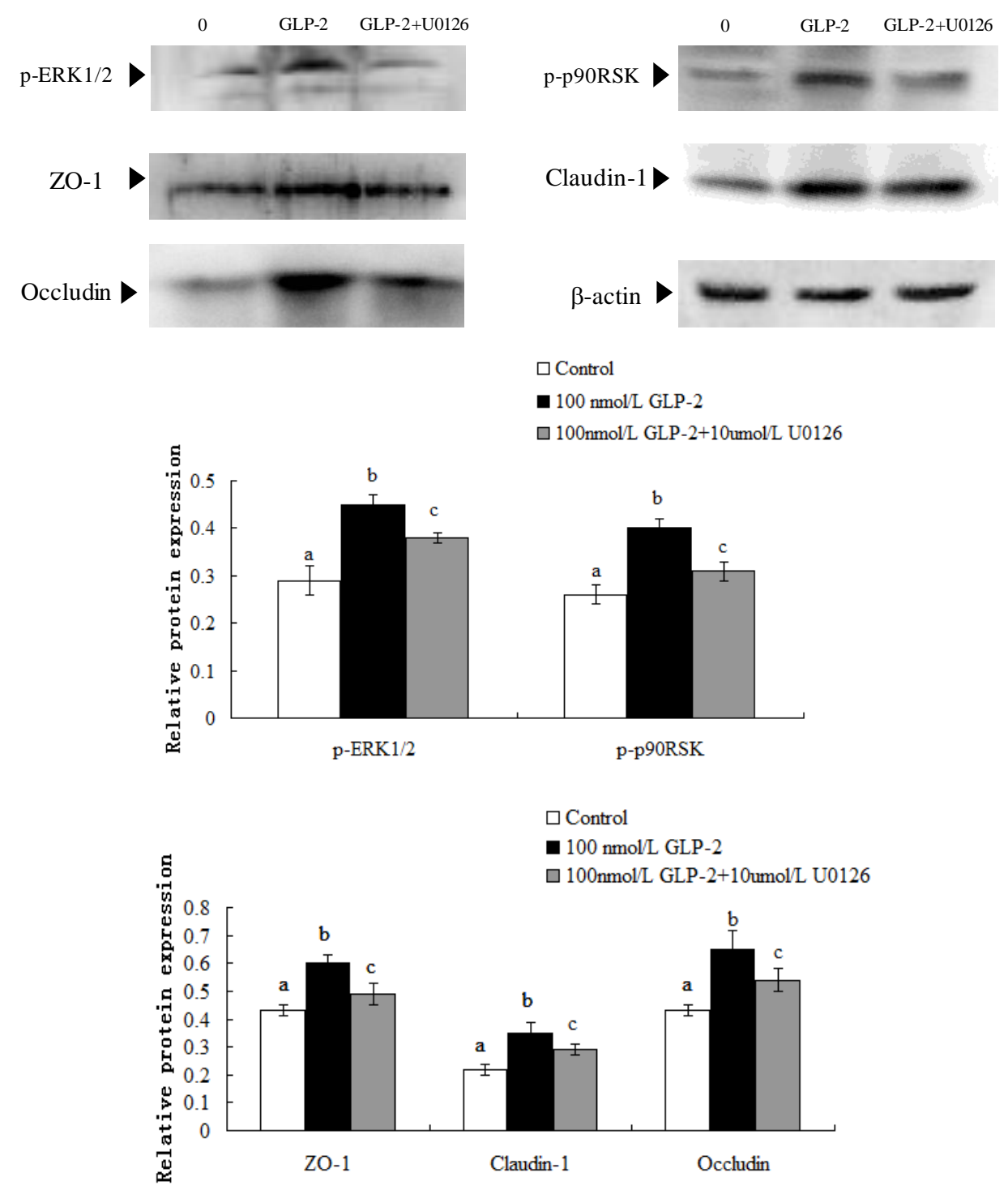

Figure 4. Effect of GLP-2 (100 nmol/L) on tight junction proteins and signaling molecules expression with MAPK signaling pathway blocked by U0126 (10 $\mu \mathrm{mol} / \mathrm{L})$. GLP-2, glucagon-like peptide 2; MARK, mitogen-activated protein kinase; ZO-1, zonula occludens-1. ${ }^{a, b, c}$ Treatments with different letters are different at $\mathrm{p}<0.05$.

into the medium, the relative abundance of p-ERK1/2, pp90RSK, ZO-1, claudin-1, and occludin significantly decreased $14.4 \%, 20.9 \%, 17.2 \%, 24.6 \%$, and $12.6 \%$ respectively $(\mathrm{p}<0.05)$.

\section{TJ proteins distribution assay}

In comparison with the control group, GLP-2 (100 nmol/L) influenced the distribution of ZO-1, occludin and claudin-1 in the tissues. The results show that the distribution of ZO-1 proteins in the GLP-2 groups presented a honeycomb appearance along the enterocyte membranes on the villus top with a more intact structure than in the control group. The occludin and claudin-1 proteins were characterized by a particle-shaped linear distribution along the intestinal villus and were more uniform than in the control group. But when U0126 (10 $\mu \mathrm{mol} / \mathrm{L})$ was added into the medium, the $\mathrm{ZO}-1$, occludin and claudin- 1 proteins presented as a vague and incoherent shape in the villus compared to the $100 \mathrm{nmol} / \mathrm{L}$ GLP-2-treated group (Figure 5).

The experimental results indicated that GLP-2 (100 $\mathrm{nmol} / \mathrm{L}$ ) increased the optical density of ZO-1, occludin and claudin-1 positive staining by $18.6 \%, 40.6 \%$, and $27.6 \%$ respectively ( $\mathrm{p}<0.05)$; while when U0126 $(10 \mu \mathrm{mol} / \mathrm{L})$ was added into the medium, the distribution of $\mathrm{ZO}-1$, occludin and claudin- 1 were sparse in the tissue and the optical density of ZO-1, occludin and claudin-1 positive staining decreased by $9.80 \%, 28.6 \%$, and $16.2 \%(\mathrm{p}<0.05)$ compared with the $100 \mathrm{nmol} / \mathrm{L}$ GLP-2-treated group (Figure 5). 


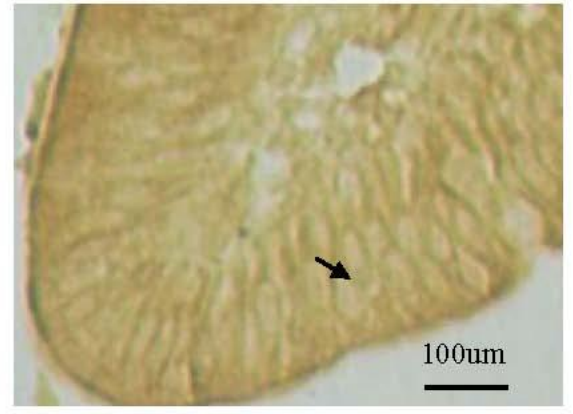

ZO-1: control

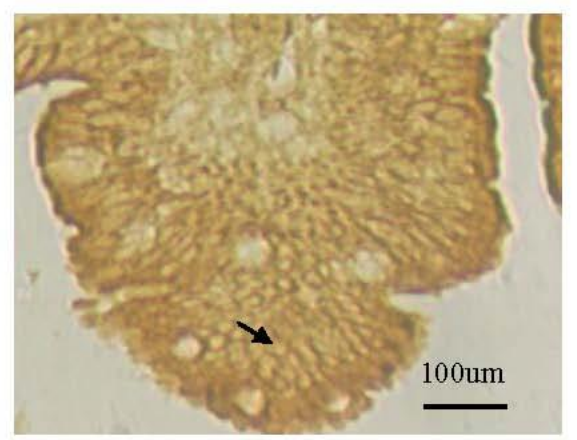

ZO-1: GLP-2 + U0126

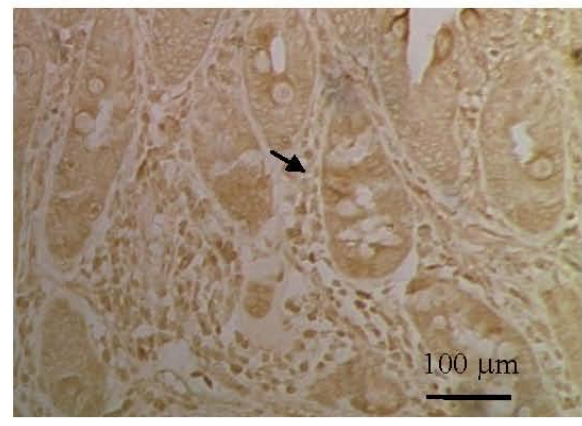

Claudin-1: GLP-2

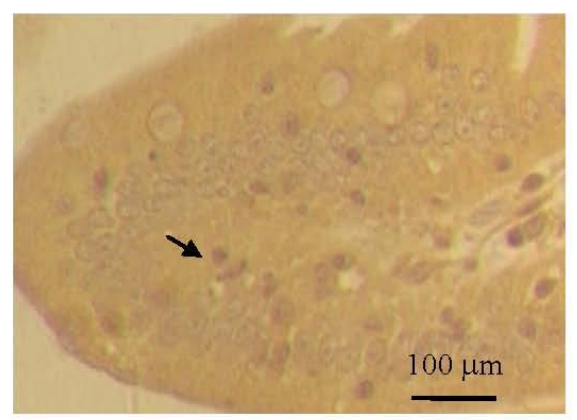

Occludin: control

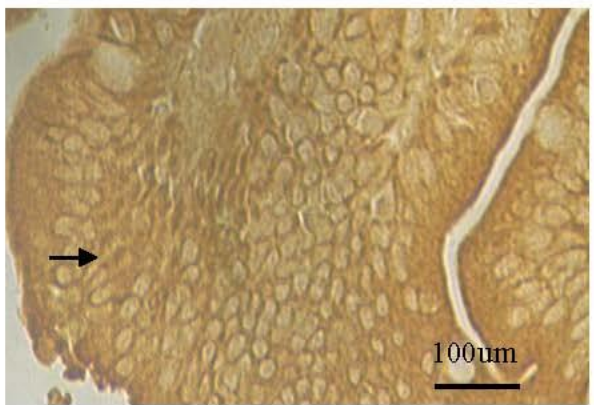

ZO-1: 100 nmol/L GLP-2

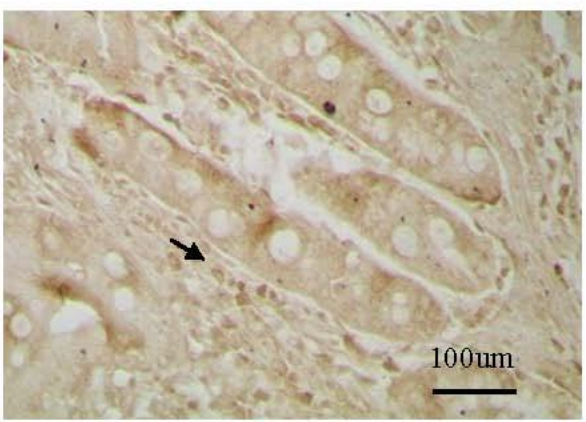

Claudin-1: control

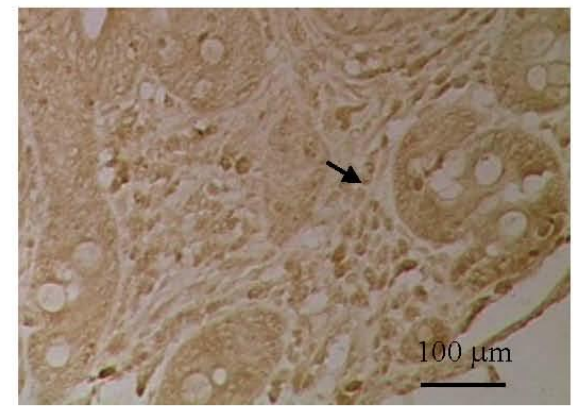

Claudin-1: GLP-2 + U0126

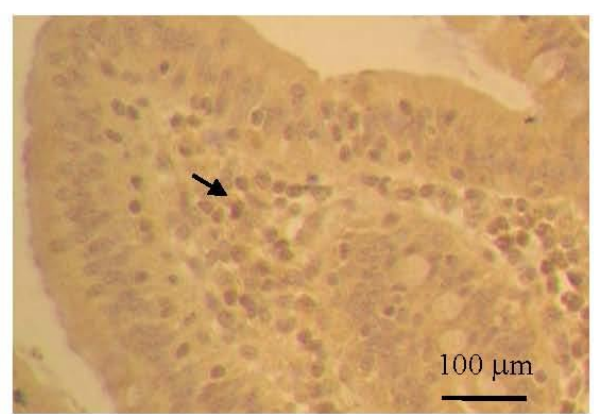

Occludin: GLP-2

Figure 5. i) Effect of GLP-2 (100 nmol/L) on distribution of tight junction proteins with MAPK signaling pathway blocked by U0126 (10 $\mathrm{mol} / \mathrm{L})$. (400-fold increase) (OD). GLP-2, glucagon-like peptide 2; MARK, mitogen-activated protein kinase; ZO-1, zonula occludens-1. ${ }^{\mathrm{a}, \mathrm{b}, \mathrm{c}}$ Treatments with different letters are different at $\mathrm{p}<0.05$. 


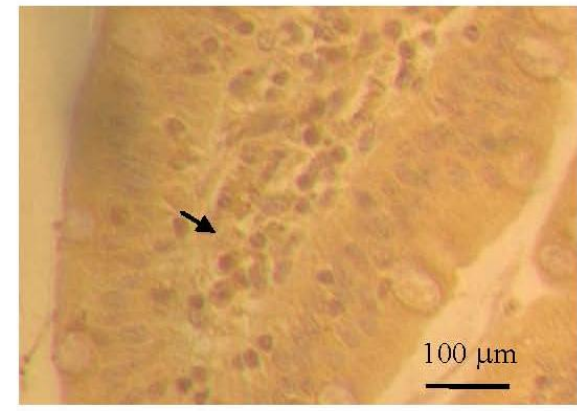

Occludin: GLP-2 + U0126

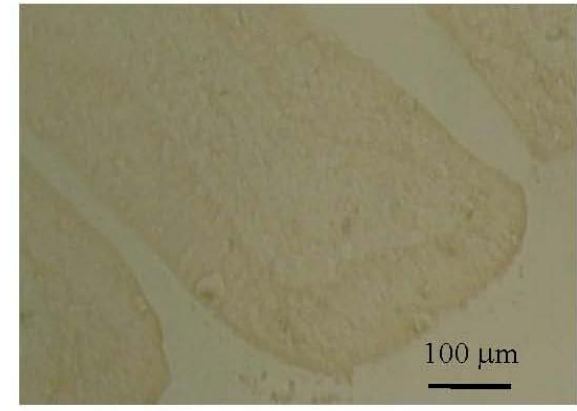

Negative control

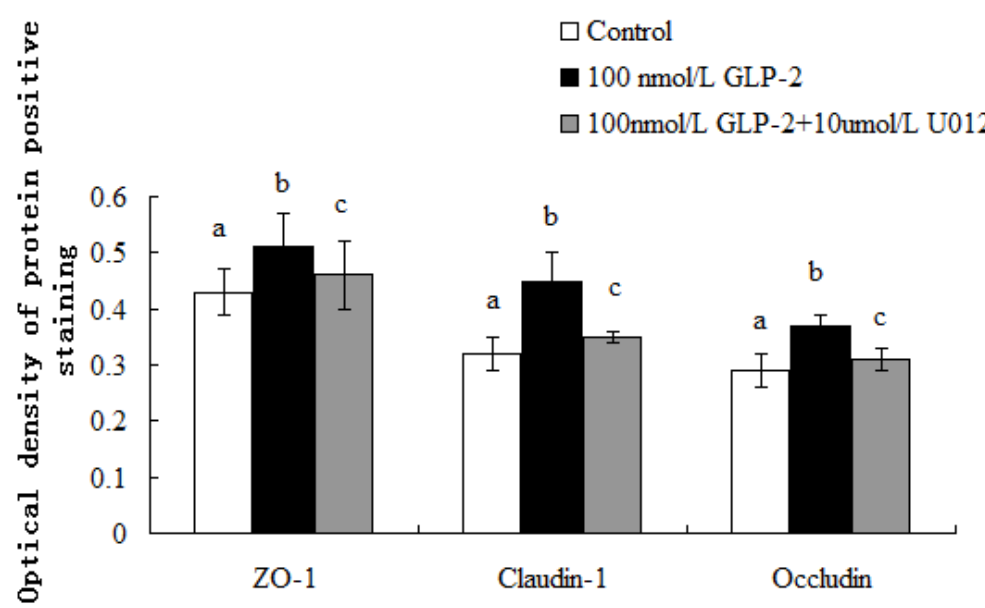

Figure 5. ii) Effect of GLP-2 (100 nmol/L) on distribution of tight junction proteins with MAPK signaling pathway blocked by U0126 $(10 \mu \mathrm{mol} / \mathrm{L})$. (400-fold increase) (OD). GLP-2, glucagon-like peptide 2; MARK, mitogen-activated protein kinase; ZO-1, zonula occludens-1. ${ }^{a, b, c}$ Treatments with different letters are different at $\mathrm{p}<0.05$.

\section{DISCUSSION}

As a physiological regulator of mucosal epithelial homeostasis, GLP-2 plays an important role in intestinal health. The available evidence suggests that GLP-2 has the function of regulating the mucosal integrity, permeability and nutrient absorption. GLP-2 may potentially exert therapeutically favorable effects on diseases induced by injury or dysfunction of the gastrointestinal epithelium (Drucker et al., 2002). Drucker et al. (1999) found that GLP-2 had the biological function of attenuating small bowel shortening, enhancing the mucosal area and integrity in animal models experiencing inflammatory bowel disease and intestinal injury. These effects may be due to an increase of the mucosal DNA content and proteins by GLP2 (Kato et al., 1999; Prasad et al., 2000). The GLP-2 receptor, which expresses in a highly tissue-specific manner, distinctly mediates the functions of GLP-2 in the gut and predominantly expresses in the jejunum (Munroe et al., 1999). GLP-2 also has the function of improving the barrier primarily regulated by TJ (Torsten et al., 2001).

Tight Junction is an important junctional complex of simple epithelial cells that is located at the most-apical part of the lateral membrane and contains several unique proteins, such as claudins, the transmembrane protein occludin and ZOs. ZO-1, occludin and claudin-1 are the most important and critical components in the structural and functional organization of the TJ. Occludin is identified as the first integral membrane protein localized at $\mathrm{TJ}$ and has important functions in maintaining the integrity and barrier function of the TJ (Furuse et al., 1993). ZO-1 is an important linker protein in TJ. Its PDZ domains could bind to C-terminal sequences of claudins and its GUK domains could bind to the C-terminal tail of occludin. ZO-1 also constitutes a link between the plasma membrane and actin cytoskeleton to make the complex stable (Fanning et al., 1998). Claudin-1 was fairly tightly related to the expression of ZO-1 in the small intestine. As claudin-1 has two extra cellular loops that display variability in the distribution and number of charged residues, it is the major determinant of ionic selectivity in paracellular transport processes (Gonzalez et al., 2008).

Benjamin et al. (2000) demonstrated that GLP-2 enhanced the barrier function by reducing permeability of the intestine through both transcellular and paracellular pathways. Cameron et al. (2005) also found that GLP-2 
could reduce the bacterial penetration and colonic inflammatory cells in rats. The changes of the occludin, ZO-1 and claudin-1 mRNA expressions were determined to clarify the underlying mechanism of reducing the intestinal permeability and improving the barrier function by GLP-2 treatment. The results indicated that both 10 and 100 nmol/L additions of GLP-2 increased the claudin-1, occludin and ZO-1 mRNA expressions. Consistent with the gene observations, GLP-2 also stimulated the expressions of claudin-1, occludin and ZO-1. The results are consistant with Chen et al. (2008) who found that exogenous treatment of GLP-2 in obstructive jaundice rats increased the ZO-1, occludin, and claudin-1 expressions of intestinal mucosa. The results demonstrated that GLP-2 promoted the TJ of piglets' intestine in the ablactating stress.

An additional in vitro tissue culture experiment was carried out to understand the molecular mechanisms of TJ expression changes associated with piglets' ablactating. The results showed that both epithelial proteins and their mRNA expressions increased by adding GLP-2 to the culture medium. Besides, GLP-2 also increased phosphorylation of the mitogen-activated protein kinase ERK1/2 and its downstream target p90RSK. Similar results were also found in the neonatal piglets' intestinal cells (Burrin et al., 2007) and rat kidney fibroblasts cells (Yusta et al., 1999). Activation of ERK1/2 has been proved to be important in the responses of GLP-2 increasing the intestinal cell proliferation in rats (Jasleen et al., 2000), humans (Margaret et al., 1998; Jasleen et al., 2002) and neonatal piglets (Burrin et al., 2007). However, the function of GLP-2 activating ERK1/2 has not been demonstrated before in weaned piglets' tissue culture method in vitro.

GLP-2 could increase cell proliferation via the MAPK signaling pathway. Many research studies also revealed that the MAPK signaling pathway was able to modulate TJ paracellular transport due to the up or down regulatory effects on several TJ proteins expressions (Gonzalez et al., 2008). It is unknown whether GLP-2 also modulates the TJ protein expressions via the MAPK signaling pathway. U0126, a potent and specific mitogen-activated ERKactivating kinase inhibitor, was used to block the MAPK signaling pathway to explore whether GLP-2- induced ERK1/2 activation mechanistically links with an induction of TJ protein expressions. But once the ERK1/2 and p90RSK phosphorylation was decreased by U0126, the expressions of $\mathrm{TJ}$ proteins decreased significantly. In addition, the activation of ERK1/2 and subsequent p90RSK may involve the TJ protein expressions. A linkage between TJ proteins and barrier function in the intestine suggests that GLP-2 may modulate the intestinal barrier function via the ERK1/2 signaling pathway, although the effects of GLP-2 treatment on the permeability were not detected. However, other studies on various cells have shown that
ERK1/2 activation is necessary for normal barrier function restoration. Wachtel et al. (2002) suggested that ERK1/2 activation was necessary for the induction of paracellular hyperpermeability under hypoxic conditions. In epithelia cells, it also has been observed that several growth factors such as transforming growth factor $\beta$ (Howe et al., 2005; Feldman et al., 2007), epithelial growth factor (EGF) (Basuroy et al., 2006) and HGF (Lipschutz et al., 2005) could activate the ERK1/2 to promote the barrier function of TJ.

\section{CONCLUSION}

In this experiment, the GLP-2 treatment significantly increased the ERK1/2, p90RSK, ZO-1, occludin, claudin-1 and their mRNA relative expressions and distribution. The TJ mRNA and protein expressions decreased significantly when U0126 was used to block the MAPK signaling pathway. These results suggested that GLP-2 improves intestinal tight junction expression in weaned pigs through MAPK signaling pathway.

\section{ACKNOWLEDGEMENTS}

This research was supported by Sichuan Provincial Education Department of Outstanding Academic and Technical Youth Leadership Fund (2010JQ0043). We are also grateful to Animal Biotechnology Center, Sichuan Agricultural University.

The work was supported by Sichuan Provincial Education Department of Outstanding Academic and Technical Youth Leadership Fund (2010JQ0043), China.

\section{REFERENCES}

Basuroy, S., A. Seth, B. Elias, A. P. Naren, and R. Rao. 2006. MAPK interacts with occludin and mediates EGF-induced prevention of tight junction disruption by hydrogen peroxide. Biochem. J. 393:69-77.

Benjamin, M. A., D. M. McKay, P. C. Yang, H. Cameron, and M. H. Perdue. 2000. Glucagons-like peptide-2 enhances intestinal epithelial barrier function of both Tran cellular and Para cellular pathways in the mouse. Gut 47:112-119.

Bruewer, M., A. Luegering, T. Kucharzik, C. A. Parkos, J. L. Madara, A. M. Hopkins, and A. Nusrat. 2003. Proinflammatory cytokines disrupt epithelial barrier function by apoptosis-independent mechanisms. J. Immunol. 171: 6164-6172.

Burrin, D. G., Y. Petersen, B. Stoll, and P. Sangild. 2001. Glucagon-like peptide 2: A nutrient-responsive gut growth factor. J. Nutr. 131:709-712.

Burrin, D. G., B. Stoll, X. F. Guan, L. W. Cui, X. Y. Chang, and D. Hadsell. 2007. GLP-2 rapidly activates divergent intracellular signaling pathways involved in intestinal cell survival and proliferation in neonatal piglets. Am. J. Physiol. Endocrinol. 
Metab. 292:E281-E291.

Cameron, H. L. and M. H. Perdue. 2005. Stress impairs murine intestinal barrier function: improvement by glucagon-like peptide-2. J. Pharmacol. Exp. Ther. 314:214-220.

Cameron, H. L., P. C. Yang, and M. H. Perdue. 2003. Glucagonlike peptide-2-enhanced barrier function reduces pathophysiology in a model of food allergy. Am. J. Physiol. Gastrointest. Liver Physiol. 284:G905-G912.

Chen, Z. Y., X. S. Feng, and P. Yang. 2008. Effect of glucagon-like peptide-2 on modulation of intestinal epithelium tight junction in rats with obstructive jaundice. Chi. J. Gener. Surg. 17:760763.

Drucker, D. J. 2002. Gut adaptation and the glucagon-like peptides. Gut 50:428-435.

Drucker, D. J., B. Yusta, R. P. Boushey, B. L. DeForest, and P. L. Brubaker. 1999. Human [Gly2] GLP-2 reduces the severity of colonic injury in a murine model of experimental colitis. Am. J. Physiol. Gastrointest. Liver Physiol. 276:G79-G91.

Fanning, A. S., B. J. Jameson, L. A. Jesaitis, and J. M. Anderson. 1998. The tight junction protein ZO-1 establishes a link between the Tran membrane protein occludin and the actin cytoskeleton. J. Biol. Chem. 273:745-753.

Favata, M. F., K. Y. Horiuchi, E. J. Manos, A. J. Daulerio, D. A. Stradley, W. S. Feeser, D. E. Van Dyk, W. J. Pitts, A. E. Richard, F. Hobbs, R. A. Copeland, R. L. Magolda, P. A. Scherle, and J. M. Trzaskos. 1998. Identification of a novel inhibitor of mitogen activated protein kinas. J. Biol. Chem. 273:18623-18632.

Feldman, G., B. Kiely, N. Martin, G. Ryan, T. McMorrow, and M. P. Ryan. 2007. Role for TGF-beta in cyclosporine-induced modulation of renal epithelial barrier function. J. Am. Soc. Nephrol. 18:1662-1671.

Furuse, M., T. Hirase, M. Itoh, A. Nagafuchi, S. Yonemura, S. Tsukita, and S. Tsukita. 1993. Occludin: A novel integral membrane protein localizing at tight junctions. J. Cell Biol. 123:1777-1788.

Gonzalez-Mariscal, L., R. Tapia, and D. Chamorro. 2008. Crosstalk of tight junction components with signaling pathways. Biochim. Biophys. Acta 1778:729-756.

Howe, K. L., C. Reardon, A. Wang, A. Nazli, and D. M. McKay. 2005. Transforming growth factor-beta regulation of epithelial tight junction proteins enhances barrier function and blocks enterohemorrhagic Escherichia coli $\mathrm{O}_{157}: \mathrm{H}_{7}$-induced increased permeability. Am. J. Pathol. 167:1587-1597.

Jasleen, J., S. W. Ashley, N. Shimoda, M. J. Zinner, and E. E. Whang. 2002. Glucagon-like peptide 2 stimulates intestinal epithelial proliferation in vitro. Digest. Dis. Sci. 47:1135-1140.
Jasleen, J., N. Shimoda, E. R. Shen, A. Tavakkolizadeh, E. E. Whang, D. O. Jacobs, M. J. Zinner, and S. W. Ashley. 2000. Signaling mechanisms of glucagons-like peptide 2-induced intestinal epithelial cell proliferation. J. Surg. Res. 90:13-18.

Kansagra, K., B. Stoll, C. Rognerud, H. Niinikoski, N. O. Ching, R. Harvey, and D. Burrin. 2003. Total parenteral nutrition adversely affects gut barrier function in neonatal piglets. Am. J. Physiol. Gastrointest. Liver Physiol. 285:G1162-G1170.

Kato, Y., D. Yu, and M. Z. Schwartz. 1999. Glucagonlike peptide2 enhances small intestinal absorptive function and mucosal mass in vivo. J. Pediatr. Surg. 34:18-21.

Kucharzik, T., S. V. Walsh, and J. Chen. 2001. Neutrophil transmigration in inflammatory bowel disease is associated with differential expression of epithelial intercellular junction proteins. Am. J. Pathol. 159: 2001-2009.

Lipschutz, J. H., S. Li, A. Arisco, and D. F. Balkovetz. 2005. Extracellular signal-regulated kinases $1 / 2$ control claudin-2 expression in Madin-Darby canine kidney strain I and II cells. J. Biol. Chem. 280:3780-3788.

Munroe, D. G., A. K. Gupta, F. Kooshesh, T. B. Vyas, G. Rizkalla, H. Wang, L. Demchyshyn, Z. J. Yang, R. K. Kamboj, H. Chen, K. McCallum, M. Sumner-Smith, D. J. Drucker, and A. C. Prototypic. 1999. Prototypic G protein-coupled receptor for the intestinotrophic factor glucagon-like peptide 2. Proc. Natl. Acad. Sci. USA 96:1569-1573.

Osek, J. 1999. Prevalence of virulence factors of Escherichia coli strains isolated from diarrheic and healthy piglets after weaning. Vet. Microbiol. 68:209-217.

Pfaffl, M. W. 2001. A new mathematical model for relative quantification in real time RT-PCR. Nucl. Acids Res. 29 (9):e45.

Prasad, R., K. Alavi, and M. Z. Schwartz. 2000. Glucagonlike peptide-2 analogue enhances intestinal mucosal mass after ischemia and reperfusion. J. Pediatr. Surg. 35:357-359.

Tsukita, S., M. Furuse, and M. Itoh. 2001. Multifunctional strands in tight junctions. Nat. Rev. Mol. Cell Biol. 2:285-293.

Wachtel, M., K. Frei, E. Ehler, C. Bauer, M. Gassmann, and S. M. Gloor. 2002. Extracellular signal-regulated protein kinase activation during reoxygenation is required to restore ischaemia-induced endothelial barrier failure. Biochem. J. 367: 873-879.

Yusta, B., R. Somwar, F. Wang, D. Munroe, S. Grinstein, A. Klip, and D. J. Drucker. 1999. Identification of glucagons-like peptide-2 (GLP-2) activated signaling pathways in baby hamster kidney fibroblasts expressing the rat GLP-2 receptor. J. Biol. Chem. 274:30459-30467. 